\title{
Reflections
}

\section{Welcome, its suppression, and the in-between spaces of refugee sub-citizenship - commentary to Gill}

\author{
MATTHEW SPARKE
}

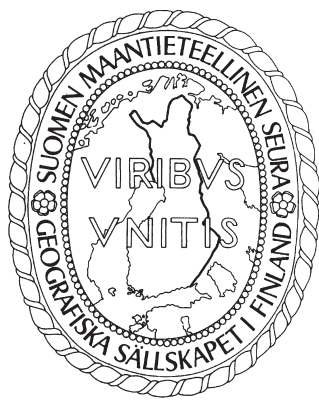

Sparke, M. (2018) Welcome, its suppression, and the in-between spaces of refugee sub-citizenship - commentary to Gill. Fennia 196(2) 215-219. https://doi.org/10.11143/fennia.70999

This article argues that geographies of welcome complicate simple binary oppositions between fully enfranchised citizenship and what is often theorized as the 'bare life' of refugee rejection in 'spaces of exception'. Ranging from sanctuary cities and squats to clinics, classrooms, kitchens and gardens, spaces of welcome instead offer islands of limited enfranchisement, agency and hope amidst seas of sub-citizenship, subjugation and fear. The concept of sub-citizenship can be used thus to elucidate how welcome and its suppression create a spectrum of intermediate experiences between the abstract poles of biopolitical belonging and necropolitical rejection. Geographies of welcome thereby become legible as in-between spaces in which the damage done by the suppression of welcome is contested and countered, however incompletely.

Keywords: migration, refugees, sanctuary, sub-citizenship, biopolitics

Matthew Sparke, Politics Department, Merrill, UCSC, Santa Cruz, CA 95064, USA. E-mail: msparke@ucsc.edu

Inspired by Nick Gill's invitation to reflect on the suppression of welcome for refugees, I would like to use this commentary to highlight how spaces of welcome complicate simple binary oppositions between fully enfranchised citizenship and what is often theorized after Agamben (2000) as the 'bare life' of refugee rejection in 'spaces of exception' (but see Owens 2009). Ranging from sanctuary cities and squats to clinics, classrooms, kitchens and gardens, spaces of welcome instead offer islands of limited enfranchisement, agency and hope amidst seas of sub-citizenship, subjugation and fear. The concept of sub-citizenship can be used thus to elucidate how welcome and its suppression create a spectrum of intermediate experiences between the abstract poles of biopolitical belonging and necropolitical rejection (Sparke 2017). Geographies of welcome thereby become legible as in-between spaces in which the damage done by the suppression of welcome is contested and countered, however incompletely.

Similar to the 'in-between space' traced by Puar (2017) as subtending the disabled/non-disabled binary, geographies of welcome can be understood as offering 'capacitation' amidst 'debilitation' (ibid., xvii). Conceptualizing sub-citizenship in this way, we can also follow Gill to notice how social struggles to expand refugee inclusion, agency and movement in everyday life are in ongoing embodied tension with the bureaucratization of humanitarian welcome as well as with the obliteration of welcome by state and non-state terror (Gill 2018). In turn, the complex geographies of all the resulting in-between spaces complicate critiques of liberal humanitarianism, neoliberal exception and illiberal expulsion that assume some sort of absolute ontological divide between citizenship and its exceptional others. As Vuolteenaho and Lyytinen (2018) suggest in their own response to Gill, such critical geographical 


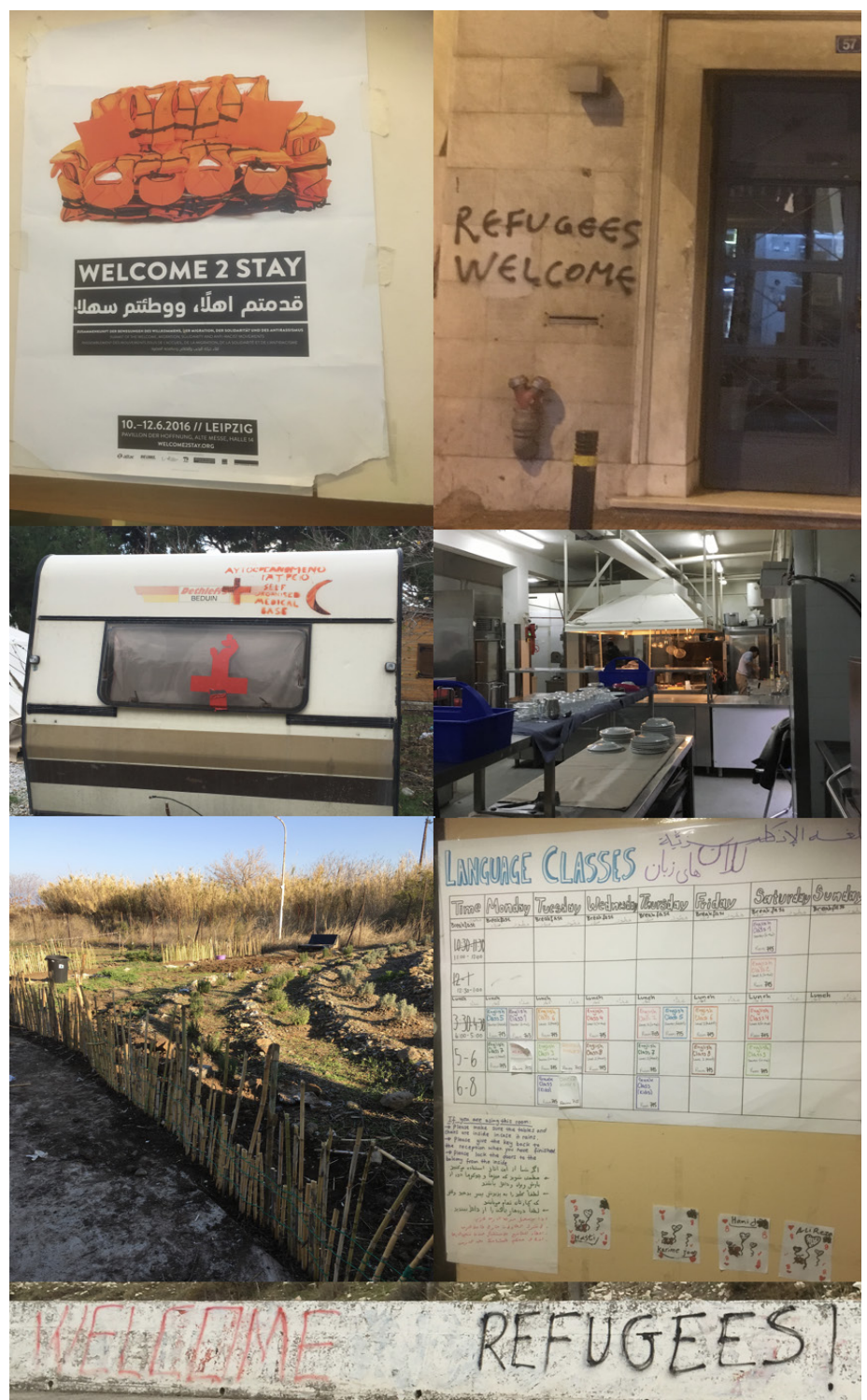

Fig. 1. Photographs (by Matthew Sparke) of welcome featuring - clockwise from top left - a poster at the entrance to the City Plaza lounge-bar, Athens street graffiti, the kitchen that prepares free food everyday at City Plaza, sign-up sheet for classes at City Plaza, Lesvos graffiti, the garden at Lesvos Solidarity, and the clinic caravan at Lesvos Solidarity. jackets at all: deaths that have in turn been shown with forensic analysis to be directly attributable to the EU's suppression of welcome at sea (Heller \& Pezzani 2018).

It needs to be remembered, therefore, that in-between spaces of welcome are in constant danger of being overwhelmed by the forces of suppression. As easily linked as they are as representational space in photographs and articles, the suppression of welcome has continued to operate in the opposite direction - including through bureaucratic re-presentations of the same spaces - to reduce the in-between spatial practices available to refugees, pushing their experiences of sub-citizenship sensitivity further brings into focus "more ambiguous and contextually varying attitudes to (un)welcoming immigrants" (ibid., 118).

In Greece in December 2016 many scenes testified to the wide variety and ambiguity of spaces of welcome (Fig. 1). From street graffiti and the successful City Plaza hotel squat in Athens to Lesvos Solidarity's camp for especially vulnerable refugees in a former summer camp for children, such spaces of welcome were easy to find during a three-week research visit. ${ }^{1}$ They included informal everyday solidarity spaces such as kitchens and couches, as well as humanitarian care sites such as clinics. They also featured schooling spaces for children that were evolving over time to include connections between volunteer-run classrooms on-site and off-site local government schools. Such connections, though, were very hard won and tenuous. More generally the connections across the overall archipelago of welcome remained extremely precarious, frequently overwhelmed by the violence of suppression across a wide variety of scales. At City Plaza the poster (created by an allied German refugee solidarity group) featuring life jackets transformed into a welcoming couch signaled a resistant recoding of this precarity. It could be read thus as a reminder at the entrance to the squat's lounge-bar with its own welcoming couches that welcome across the EU remains haunted by all the refugees who have died at sea wearing fake life-jackets or no life- 


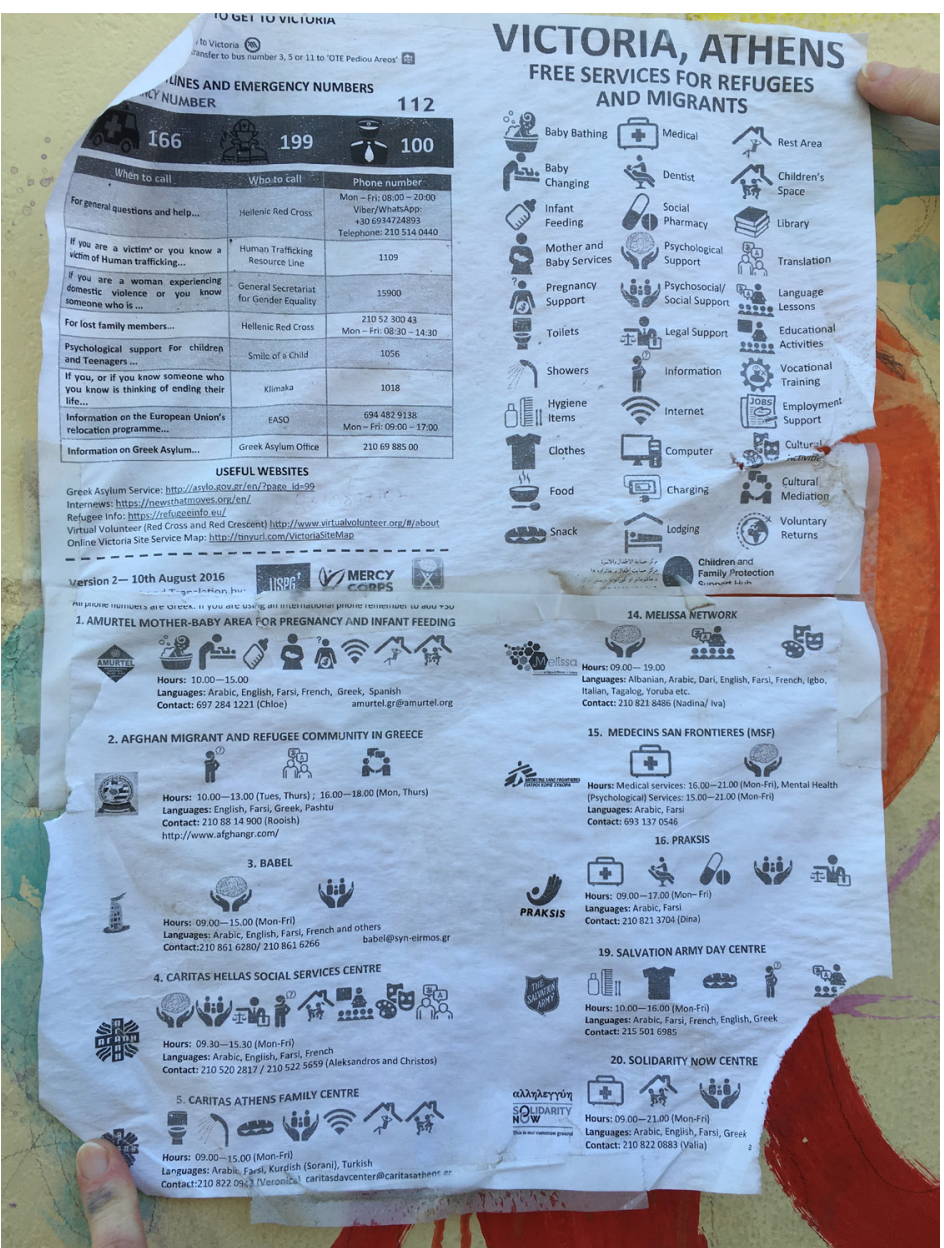

Fig. 2. Poster at Lesvos Solidarity articulating with welcome in Athens and prefiguring citizenship rights to free services. Photograph by Matthew Sparke. back towards the pole of active exclusion and rejection, or, just as damagingly, violent inaction (Davies et al. 2017). Pulling in the opposite direction, refugee solidarity work provides practical guides for navigating between the welcome spaces with agency and autonomy. City Plaza has been able in this way to help many of its residents connect to welcome elsewhere in Europe, and a poster on the wall at Lesvos Solidarity highlighted the elaborate ecosystem of welcome spaces available to refugees making the journey from Lesvos to the area in Athens close to City Plaza (Fig. 2). These, then, are articulatory politics in both a very practical sense of connecting sites of welcome as well as in the sense of articulating a kind of counter-public of welcome within a wider field of suppressionist hegemony. In these ways they also articulate ideas about biopolitical belonging representationally, prefiguring a wider form of political enfranchisement too, and thereby anticipating the broad-based refugee services, health rights and human rights that would turn sub-citizenship into more fully fledged forms of social and civil citizenship. But it

is precisely such articulatory and prefigurative movements - movements towards citizenship and refugee agency - that have been disabled by the suppression of welcome, trapping refugees in limbo and sub-citizenship. It is to these kinds of suppression that we now turn, and at least three different versions need to be disaggregated.

First, there are all the illiberal exclusion effects created by rising rejectionism and xenophobia globally. President Donald Trump's dehumanizing racist rhetoric about immigrants from 'shithole' countries and his administration's increasing militarization of US borders are only the most egregious examples of this reactionary suppression of welcome around the world. Most countries and contexts have their own mix of racist or religious rationales for such rejectionism, and yet it appears that these distinctive regional reaction formations are also now inter-articulating globally alongside the same market globalization that so often sets the scene for their expressions of xenophobic nationalism (Sparke 2013, chapter 10). Following feminist geographers, we clearly need to address the emotional and intimate political geographies animating these global dynamics (Hyndman \& Mountz 2006). And thus alongside the emotion of welcome underlined by Gill, it is also critical to remember how reactionary rejectionism globally is itself articulated emotionally, albeit through the personal production of hate instead of hope (compare Mostafenezhad 2017; and Gökariksel \& Smith 2018). In 
turn, the resulting suppression of welcome and the associated stigmatization of refugees as bringing global threats of disease, crime and terror lead towards all sorts of new border control and deportation dynamics that terrorize refugees at a deep emotional level too. In other words, just like welcome itself, both the production and experience of illiberal exclusion is as emotionally affective as it is practically effective (Kallio \& Riding 2018).

Second, there are the neoliberal exclusion effects of recent innovations in border-regime governmentality, innovations that in Europe range from the economically-incentivized outsourcing of frontier policing to non-EU neighbors in North Africa and Turkey to the implementation of the Hotspot programs in frontline countries such as Greece(Painter etal. 2016). Denationalizing and deterritorializing in terms of pan-European coordination and biometric data collection, they simultaneously renationalize and re-territorialize borders onto unprivileged bodies like other biometrics systems elsewhere (Sparke 2009). Often announced in the name of reducing deaths at sea and efficiently triaging asylum applications, these programs have in practice widely compounded the dangers facing refugees, turning welcome into waiting or deportation, and making the safe movements supported by solidarity groups into increasingly unsafe journeys, including unsafe returns to unsafe spaces that are nevertheless declared 'safe' in order to comply administratively with the Geneva conventions.

In each of these cases it is possible to see how solidarity around welcome continues to work against suppression to contest and counter the illiberal and neoliberal exclusions. But what of liberal humanitarianism and its limits? Both City Plaza and Lesvos Solidarity have sought to set themselves apart from other more traditional liberal humanitarian projects that have been bureaucratized and instrumentalized as a result of their involvement in the co-management of reception in places such as the Hotspots. But they also illustrate the importance of Gill's (2018) argument about the need to recognize how welcome sometimes involves compromise and cooperation with liberal and even neo-liberal state-making - thereby underlining the importance of Bagelman's (2018) question about 'who hosts?'. Creating local school access for refugee children has been an example of this kind of cooperation in both cases. Lesvos Solidarity is further involved in various grant-funded entrepreneurial efforts to create work opportunities for refugees that in turn raise funds for small acts of enfranchisement like providing free bus tickets - thereby enabling micro-movements between spaces of welcome on Lesvos with micro-spaces of enterprise. Set against small advancements in enfranchisement like this, and attuned to their liberal and neoliberal compromises, it seems mistaken to move from abstract critiques of liberal humanitarianism to assumptions of it inevitably being controlling, exclusionary and exceptionalist. Instead, Gill's call to examine the suppression of welcome reminds us that in-between spaces may be linked up with the liberal humanitarian management of welcome to offer sanctuary amidst sub-citizenship (see also Carney et al. 2018). By countering and contesting exclusion and exception such efforts might further be understood as articulating and prefiguring the wider enmeshment of refugee resilience with resistance too (Bourbeau \& Ryan 2017). And by illustrating ongoing opportunities for such agency in the face of suppression, they surely also suggest that we need to abandon or at least supplement abstract critiques of liberal humanitarianism that assume that exceptionalism and rejectionism are always and everywhere inevitable.

\section{Notes}

1 For more information on City Plaza see their Facebook page at https://www.facebook.com/ sol2refugeesen/. For more information on Lesvos Solidarity (previously known as Pikpa) see their website at https://lesvossolidarity.org/en/.

\section{Acknowledgements}

Many thanks to Kirsi Pauliina Kallio and the excellent editorial team at Fennia for all their work in supporting the innovative open review process and associated discussions enabled by Nick Gill's important intervention. 


\section{References}

Agamben, G. (2000) Means without End: Notes on Politics. Translated by V. Binetti \& C. Casarino. University of Minnesota Press, Minneapolis.

Bagelman, J. (2018) Who hosts a politics of welcome? - commentary to Gill. Fennia 196(1) 108-110. https://doi.org/10.11143/fennia.70294

Bourbeau, P. \& Ryan, C. (2017) Resilience, resistance, infrapolitics and enmeshment. European Journal of International Relations 24(1) 221-239. https://doi.org/10.1177/1354066117692031

Carney, M., Gomez, R., Mitchell, K., Vannini, S. (2018) Sanctuary planet: a global sanctuary movement for the time of Trump. Society and Space. $<$ http://societyandspace.org/2017/05/16/sanctuary-planeta-global-sanctuary-movement-for-the-time-of-trump/>

Davies T., Isakjee A. \& Dhesi, S. (2017) Violent inaction: the necropolitical experience of refugees in Europe. Antipode 49(5) 1263-1284. https://doi.org/10.1111/anti.12325

Gill, N. (2018) The suppression of welcome. Fennia 196(1) 88-98. https://doi.org/10.11143/ fennia.70040

Gökariksel B. \& Smith, S. (2018) Tiny hands, tiki torches: embodied white male supremacy and its politics of exclusion. Political Geography 62 207-215.

Heller, C. \& Pezzani, L. (2018) Mare Clausum: Italy and the EU's undeclared operation to stem migration across the Mediterranean. Forensic Oceanography, Forensic Architecture agency, Goldsmiths, University of London London. <http://www.forensic-architecture.org/wp-content/ uploads/2018/05/2018-05-07-FO-Mare-Clausum-full-EN.pdf>

Hyndman, J. \& Mountz, A. (2006) Feminist approaches to the global intimate. Womens Studies Quarterly 34 (1\&2) 446-463.

Kallio, K. \& Riding, J. (2018) Dialogical peer-review and non-profit open-access journal publishing: welcome to Fennia. Fennia 196(1) 4-8. https://doi.org/10.11143/fennia.70470

Mostafenezhad, M. (2017) Celebrity humanitarianism and the popular geopolitics of hope along the Thai-Burma border. Political Geography 58 67-76. https://doi.org/10.1016/j.polgeo.2017.02.002

Owens, P. (2009) Reclaiming 'bare life'? Against Agamben on refugees. International Relations 23(4) 567-582. https://doi.org/10.1177/0047117809350545

Painter, J., Papoutsi, A., Papada, E. \& Vradis, A. (2016) Flags flying up a trial mast: reflections on the hotspot mechanism in Mytilene. Society and Space. <http://societyandspace.org/2016/11/08/flagsflying-up-a-trial-mast-reflections-on-the-hotspot-mechanism-in-mytilenel>

Puar, J. (2017) The Right to Maim: Debility, Capacity Disability. Duke University Press, Durham. https://doi.org/10.1215/9780822372530

Sparke, M. (2009) On denationalization as neoliberalization: biopolitics, class interest and the incompleteness of citizenship. Political Power and Social Theory 20 287-300. https://doi. org/10.1108/S0198-8719(2009)0000020017

Sparke, M. (2013) Introducing Globalization: Ties, Tensions and Uneven Development. Wiley-Blackwell, New York.

Sparke, M. (2017) Austerity and the embodiment of neoliberalism as ill-health: towards a theory of biological sub-citizenship. Social Science and Medicine 187 287-295. https://doi.org/10.1016/j. socscimed.2016.12.027

Vuolteenaho, J. \& Lyytinen, E. (2018) Reflections on the variations and spatialities of (un)welcome commentary to Gill. Fennia 196(1) 118-123. https://doi.org/10.11143/fennia.70290 